\title{
A Prophet and Her General
}

In this opening chapter, we examine the structure of the book of Judges, its place within the wider national narrative of Genesis-Kings, and compositional issues and emphases in the prose account of Deborah's war with the Canaanites. We will see that conventional approaches that distinguish between an older source and its later integration into the narrative are deficient inasmuch as the first iteration of the account appears to have been much more succinct and may have been composed as an early addendum to the exodus-conquest narrative. The account grew dramatically as scribes downplayed the role of Deborah's general by attributing the crowning feat to a woman who lived on the margins of Israelite society.

\section{THE BOOK OF JUDGES AS A BRIDGE}

The book of Judges is situated at the center of the larger narrative of the nation's history, which begins with the creation of the world in Genesis and ends with the destruction of Jerusalem in the book of Kings. ${ }^{\mathrm{I}}$ To appreciate the important structural function that Judges serves in this narrative, we need to compare the literary seams connecting Genesis to Exodus and Joshua to Judges.

The story in Exodus begins with the death of the Egyptian king. A new pharaoh, who does "not know Joseph," "rises up" and adopts a radically

${ }^{\text {I }}$ For excellent and accessible English-language commentaries on the book, see Jack Sasson, Judges I-I2: A New Translation with Introduction and Commentary (New Haven: Yale University Press, 20I4); Susan Niditch Judges: A Commentary (Louisville: Westminster John Knox, 2008). 
different policy toward Israel. Whereas the book of Genesis presents Joseph and his family being welcomed to Egypt, the book of Exodus describes harassment and persecution in this country, which necessitate the nation's collective flight and voyage to a new land.

The transition to the book of Judges is remarkably similar to the transition to the book of Exodus. The opening chapters of Judges also begin with a death - not of a foreign king, but of the nation's leader Joshua. Just as a new pharaoh "rises up" in Exodus, a new generation of Israelites "rises up" in Judges. And just as the new pharaoh doesn't "know Joseph," the new generation in Judges doesn't "know Yhwh" and worships other gods. The consequence of the Israelites' actions is defeat: Yhwh brings an end to their streak of victories during the days of Joshua and allows them to be assailed by their enemies round about (Judg. 2:IO-I 5 ).

As many scholars now agree, Genesis originally had nothing to do with the narrative of the exodus and conquest. In fact, the two accounts of Israel's origins may have long competed with each other before they were spliced together to form a single narrative (see the discussion in Part I). As scribes conjoined these accounts, they had to deal with problems of transition. In Genesis, the pharaoh treats Israel with exceptional favor and generous patronage; in Exodus, the pharaoh is a genocidal tyrant. To explain this radical shift, the scribes who combined Genesis and Exodus prefaced a new introduction to the latter, which presents a different ruler taking the throne.

The narrative of the exodus and conquest concludes on a high note in the book of Joshua, with Israel's enemies subjugated and the land resting from war (see Josh. II:23). However, "the history of the monarchy," which is told in the books of Samuel and Kings, presents the nation struggling with the Philistines and Ammonites; the monarchy is born as Saul and David subjugate these enemies. Eventually, scribes welded the two works together, just as they had attached Genesis to the exodusconquest account. In this case, however, they had to bridge the gap between the triumphs recounted in Joshua and the dismal conditions faced by the nation at the beginning of the book of Samuel. Situated between these works, the book of Judges plays a pivotal role. By depicting the disintegration of the hegemony achieved by Joshua, it explains why the nation is plagued by foreign aggression in Samuel. ${ }^{2}$

${ }^{2}$ On Judges as a bridge in the national narrative, see Uwe Becker, "The Place of Judges in the So-Called Deuteronomistic History: Some Remarks on Recent Research" in Christoph Berner and Harald Samuel (eds.), Book-Seams in the Hexateuch I: The 


\section{AN OLDER SOURCE?}

While the book of Judges functions as a literary bridge in the narrative that extends from the book of Genesis to Kings, the Song of Deborah joins the Song of the Sea (Exod. I 5 ) in demarcating an epoch within this narrative. What defines the epoch is Yhwh's direct, royal sovereignty over the nation. (The Song of the Sea culminates with the proclamation of this Yhwh's reign; likewise, the Song of Deborah pits this deity against the kings of Canaan.) What comes thereafter belongs to a different age and has a different historical status from the great salvation wrought by the nation's god through the agency of Moses, Joshua, and Deborah - the three archetypal leaders in Israel's premonarchic history. ${ }^{3}$

In the new age portrayed in Judges, Yhwh repeatedly raises up leaders who "rescue/save" them from their foes. The cycle of sin and salvation progresses steadily, so that each new generation is worse than the one before (Judg. 2:19). What's remarkable is that the book presents Israel's golden age as a period in which a woman, Deborah, governs the nation. By concluding Deborah's account with a lengthy hymn (the focus of our attention in Chapters I I and I2), the book highlights her peerless performance. She is the ideal leader, and the account of her leadership conveys two of the book's central themes: I) the limits of (macho) monarchic power that undergirded ancient states and 2) the central role of volunteerism in the life of the nation.

According to the brief paragraph that prefaces Deborah's story, the Israelites returned to their evil ways after the death of Ehud; consequently,

Literary Transitions Between the Books of Genesis/Exodus and Joshua/Judges (Tübingen: Mohr Siebeck, 20I8), 339-35I.

3 The accounts of Deborah's immediate successors - Gideon, his son Abimelech, and Jephthah - all treat the issue of monarchic rule, and the concluding chapters of the book repeatedly assert that "at that time, there was no king in Israel." The Song of Hannah in I Samuel 2 likewise marks the beginning of a new monarchic era, and it reflects on this change in relation to Yhwh's royal power, which he "grants to the king" (v. Io).

The account of Deborah has more in common with what comes before than what comes after: with the exception of David's capture of Jerusalem from the Jebusites, Deborah's battle is the final one fought against a member of the "seven nations." Moreover, Yhwh fights for Israel by throwing its enemies into a "panic" (wayyāhām, 4:I 5). The first time the deity brings victory to Israel in this manner is during the exodus (Exod. I4:24). He does so again during a pivotal battle at Gibeon during the days of Joshua (Josh. I0:IO), and then one final time right before the establishment of the monarchy (I Sam. 7:IO), which the prophet Samuel commemorates with a monument that he calls "Ebenezer" (I Sam. 7:I 2). Inasmuch as this monument commemorates the end of an epoch ("thus far Yhwh has helped us"), it functions in both the topography of the nation's territory and the narrative of the nation's history as a lieu de mémoire, à la Pierre Nora. 
Yhwh sold them into the hand of a Canaanite king, who oppressed them for twenty years. The Hebrew syntax suggests that the nation stubbornly endured the two decades of oppression before turning to Yhwh for help.

After this preface, the narrative introduces Deborah and begins the account of her activities with Barak. Most scholars deem this account to represent an older written source, while they attribute the preface (Judg. 4:I-3) to an "editor" who compiled inherited materials and shaped the narrative of the book. ${ }^{4}$ By prefixing this secondary paragraph to the description of Deborah in the older account, the editor identified Deborah as the divine response to the nation's belated lament:

I The Israelites again did evil in the eyes of Yhwh-Ehud now being dead. 2 So Yhwh sold them to King Jabin of Canaan, who reigned in Hazor. His army commander was Sisera, whose base was Harosheth-Hagoyim. 3 The Israelites cried out to Yhwh for help, for he had nine hundred iron chariots and had oppressed the Israelites ruthlessly for twenty years.

4 Deborah, woman of Lappidoth, was a prophetess, and she was judging Israel at the time. 5 She used to sit under the Palm of Deborah, between Ramah and Bethel in the hill country of Ephraim, and the Israelites would come to her for judgment. 6 She summoned Barak son of Abinoam, of Kedesh in Naphtali, and said to him, "Yhwh, the god of Israel, has commanded: Go, march up to Mount Tabor, and take with you ten thousand men of Naphtali and Zebulun. 7 I will draw Sisera, Jabin's army commander, with his chariots and his troops, toward you up to the Wadi Kishon; and I will deliver him into your hands." Judg. 4:I-7

Despite the attractiveness of this neat reconstruction, it poses problems. Various clues suggest that a scribe added lines to bring the account into conformity with the narrative in Judges. For example, two clauses in verses 4-5 ("she was judging Israel at the time" and "the Israelites went up to her for judgment") recast this prophetess in the role of leader who judges Israel. ${ }^{5}$ The phenomenon can be observed throughout the book: stories of disparate local heroes - Ehud, Gideon, Jephthah, Abimelech, Samson, etc. - have been reworked and aligned into a succession of "judges" (or "saviors") who rescue the nation from its enemies. While the evidence of the editorial expansions supports the view that the Deborah-Barak account is an older written source that the putative editor/compiler of Judges integrated into his narrative, there's a persisting problem: the reader would have no clue who Jabin is in verse 7 were it not

${ }^{4}$ See, e.g., Kratz, Composition, 203.

5 Without these clauses, verses 4-6 read more smoothly: "Deborah, woman of Lappidoth, was a prophetess, who used to sit under the Palm of Deborah, between Ramah and Bethel in the hill country of Ephraim. She summoned ...." 
for the preface in verses $\mathrm{I}-3$, which is supposed to be part of the later editorial framework. To save the thesis, scholars must argue that the editor did not preserve the older source intact.

It's certainly possible that portions of the original Deborah-Barak account have been omitted or reformulated, yet it's more probable that the (originally brief) account was drafted for its present context. If so, the two supplementary clauses in verses 4-5 ("she was judging Israel at the time" and "the Israelites went up to her for judgment"), which recast Deborah as a judge of Israel, would indicate not that the putative editor of the book was drawing on an older written source but that later scribes were expanding earlier iterations of a larger narrative. That this was a work in progress can be seen from the fact that a death announcement, which concludes the other accounts, is still missing for Deborah and appears to have been added secondarily for Ehud (4:Ib; cf. 3:I I).

Whereas the book of Judges now functions as a literary bridge between the exodus-conquest narrative and the history of the monarchy in SamuelKings, it may not have been originally conceived as such. Otherwise, it's difficult to explain why the core accounts in Judges do not do a better job of making a case for the monarchy. Thus, the story of Deborah depicts the nation flourishing under her leadership, without a king standing in the way, and the following accounts of Gideon, Abimelech, and Jephthah are even more explicit in their repudiation of the monarchy, casting serious shade on the institution. As we will see, the Song of Deborah imagines and celebrates a nation ruled directly by Yhwh and "a mother in Israel"; in the absence of a king, it depends on the volunteerism of its diverse members.

A full elaboration and defense of my thesis will have to await a separate treatment, yet I would suggest that the earliest accounts in Judges were composed as appendices to the exodus-conquest narrative. The climax of the Joshua story reports that "the land had rest from its wars" (Josh. I I:23), and by concluding these appendices with similar statements (e.g., "the land had rest for forty years" in Judg. 5:3 I), their authors sought to demonstrate that the nonmonarchic rulers whom Yhwh "raises up" were repeatedly successful in restoring the peace and sovereignty that Joshua had first established. ${ }^{6}$

${ }^{6}$ According to my thesis, the additions in verse 4 are not evidence of an older, independent account that has been repurposed for the narrative of Judges; instead, they witness to the gradual separation of what were originally appendices to the Joshua story and the emergence of a new epoch/book of "judges" that follows the death of Joshua.

The Abimelech account in Judges 9 may represent an early bookend to the first appendices. Its depiction of a professional, mercenary army in the service of a (would-be) king 


\section{DEBORAH AND GIDEON}

Deborah performs her prophetic activities as a sibyl under "the Palm of Deborah." Like the Oracle of Delphi in Greece, her isolated location (Judg. 4:5) corresponds to her political independence, so that her prophecies are not corrupted by the interest of any one city, such as Ramah or Bethel. It is from this remote residence that she summons Barak ben Abinoam. All we are told about this figure is his place of origin: the northern town of Kedesh. Deborah communicates to him the word of Yhwh, whom she calls "the god of Israel."

The oracle charges Barak to go up to Mount Tabor and summon an army to himself in order to take the offensive against Sisera. The warrior executes his battle orders, rallying I०,000 warriors atop this isolated horst or inselberg. In response, Sisera, the enemy commander, musters his 900 iron chariots and his infantry in the valley near the Kishon River - a level playing field that has witnessed massive chariot and tank battles over the past five millennia. ${ }^{7}$ The enemy's professional forces and sophisticated armaments prove to be no match for Barak's thousands. The latter descend in a "blitz" (both this German term and the name Barak mean lightning) and wipe out the Canaanite forces.

The point of the story is a common one in biblical literature. By mobilizing large numbers of volunteers who fight under the banner of their national deity, Israel can withstand the superior weapons and professional forces of the surrounding kingdoms. For a people who lack formidable military technology, strength is in the numbers: a large force of citizen-soldiers often can withstand a smaller, elite, well-equipped army. Yet this brief tale is less about military strategy than about the ideals of volunteerism and what we today call civic duty. As such, it serves as a fitting backdrop to the following, and much more elaborate, account of Gideon.

Like the Deborah-Barak story, the Gideon account treats questions of national belonging in terms of the voluntary contributions of Israel's tribes to a war effort. Remnants of what appears to be an older account

stands in stark contrast to the collective, national nature of military contributions in the preceding accounts. The immediately following accounts develop this aspect, with Jephthah commanding a band of desperadoes and Samson acting in isolation. In the final chapters, the nation finally comes together to wage war, but the enemy is now one of their own.

${ }^{7}$ For a survey of these battles, see Eric H. Cline, The Battles of Armageddon: Megiddo and the Jezreel Valley from the Bronze Age to the Nuclear Age (Ann Arbor: University of Michigan Press, 2000). 
present Gideon as a warlord with a private army of 300 professional fighters. The scribes who drew excerpts from this older account transformed the hero into a timorous farmer; likewise, they made his elite force into a small and unskilled portion of a much larger volunteer army.

The new version of the Gideon account tells how a huge multitude answers his call to arms. Since "Israel might claim for themselves the glory," Yhwh commands Gideon to discharge "all who fear and tremble." When ro,००o troops remain, precisely the size of Barak's force, Yhwh is still not satisfied, and he commands the hero to reduce his army again (Judg. 6:34-35, 7:2-8). In the end, Gideon is left with a force of $300-$ the original size of his private army in what appears to be an older source $(7: 16,8: 4)$.

In this way, scribes transformed the identity of Gideon's 300 : they are no longer professional warriors and seasoned soldiers but farmers who volunteer for military service in an ad hoc war effort. As such, they rout the enemy not with martial savoir faire but with clever ruses and divine assistance. The heavily reworked Gideon account shares with the Deborah-Barak story an emphasis on volunteerism and the participation of Israel's tribes, yet whereas Barak triumphs because of the size of his army, Gideon succeeds thanks to divine support and subterfuge. ${ }^{8}$

\section{THE JAEL EPISODE}

The earliest iteration of the Deborah-Barak account likely didn't include the episode with Jael. On the basis of parallels with other biblical battle stories, we would expect the account to conclude in Judges 4:I6 - "The whole camp of Sisera fell by the sword; none remained" - which resembles the conclusion of many other battle stories. ${ }^{9}$ When we're told that the whole army of Sisera fell in battle and that no one survived, we should assume that this really means no one - neither the soldiers nor their commander. Yet, surprisingly, in the next paragraph (vv. I7-22), which is formulated in a different style and with much greater detail, Sisera is still alive and fleeing to the tent of Jael, the wife of one of his allies.

\footnotetext{
8 See Wright, "Gideon Narrative."

9 Thus, the battle story in I Samuel I I concludes in verse I Ib: "The survivors scattered; no two remained together." (Verses I $2-\mathrm{I} 3$ appear to be a late insertion connected to I0:27; the conclusion goes from verse Irb to verse I5.) The verb $\check{s} \bar{a}$ ar (remain) is employed frequently in this manner (see, e.g., Exod. I4:28; Josh 8:22, IO:28-40, II:IO, 22). See my article, "Deborah's War Memorial."
} 
As scribes added the Jael episode, they made changes to other parts of the Deborah-Barak account, and the perceptive reader can easily retrace their moves. Thus, the statement about Jael's husband Heber in verse I I stands isolated in its context; a scribe apparently found this transitional point to be a suitable place to insert an explanation of why Sisera later trusts Jael. ${ }^{\text {Io }}$ Similarly, Deborah's surprising prophecy to Barak in verse $9 \mathrm{~b}$ is easy to identify as an interpolation: originally, Deborah prophesies that Yhwh would deliver Sisera into Barak's hand (v. 7), while here she declares that Yhwh would deliver the enemy general into the hand of a woman. Another place is the description of Sisera descending from his chariot and fleeing on foot to the tent of Jael (vv. I $5 b-16 a)$. While the older portion presents Barak pursuing all the chariots back to the place whence they came, the reader now knows that Sisera is elsewhere and on foot. Similarly, while the older portion reports that "the entire camp of Sisera fell by the sword," the reader must now conclude that this means only Sisera's camp, not Sisera himself.

\section{The Composition of Judges 4}

\section{Preface}

I The Israelites again did evil in the sight of Yhwh - Ehud now being dead. 2 So Yhwh sold them to King Jabin of Canaan, who reigned in Hazor. His army commander was Sisera, whose base was in Harosheth-Hagoyim. 3 The Israelites cried out to Yhwh for help, for he had nine hundred iron chariots and had oppressed the Israelites ruthlessly for twenty years.

\section{Deborah Commissions Barak}

4 Deborah, woman of Lappidoth, was a prophetess, and she was judging Israel at the time. 5 She used to sit under the Palm of Deborah between Ramah and Bethel in the hill country of Ephraim, and the Israelites would come to her for judgment. 6 She summoned Barak son of Abinoam, of Kedesh in Naphtali, and said to him, "Yhwh, the god of Israel, has commanded: Go, march up to Mount Tabor, and take with you ten thousand men of Naphtali and Zebulun. 7 I will draw Sisera, Jabin's army commander, with his chariots and his troops, toward you up [to the Wadi Kishon]; and I will deliver him into your hands.”

8 Barak said to her, "If you will go with me, I will go; but if you will not go with me, I will not go." 9 And she said, "I will surely go with you; nevertheless, the road on which you are going will not lead to your own glory, for Yhwh will sell Sisera into the hand of a woman." Then Deborah arose and went with Barak to Kedesh.

Io The Jael episode presupposes that Sisera's army consisted of a coalition that included other peoples, such as the Kenites, but the initial description of Sisera's forces refers only to "his chariots" and "the troops who were with him" in Harosheth-Hagoyim (v. I3). 


\section{The Campaign}

Io Barak summoned Zebulun and Naphtali to Kedesh, and ten thousand foot soldiers went up - and also Deborah went up with him.

I I Now Heber the Kenite had separated from the other Kenites, that is, the descendants of Hobab the father-in-law of Moses, and had encamped as far away as Elon-Bezaanannim, which is near Kedesh.

I 2 Sisera was told that Barak son of Abinoam had gone up to Mount Tabor.

I 3 Sisera called out all his chariots, nine hundred chariots of iron, and all the troops who were with him, from Harosheth-Hagoyim to the Kishon River. I4 Then Deborah said to Barak, “Up! For this is the day on which Yhwh has given Sisera into your hand. Yhwh is indeed going out before you." So Barak went down from Mount Tabor with ten thousand warriors following him. I5 And Yhwh threw Sisera, all his chariots, and indeed his entire camp into panic before the sword of Barak.

Sisera got down from his chariot and fled away on foot, I 6 while Barak pursued the chariotry and the camp to Harosheth-Hagoyim.

The entire camp of Sisera fell by the sword; none remained.

Jael Episode

I 7 Now Sisera had fled away on foot to the tent of Jael wife of Heber the Kenite; for there was peace between King Jabin of Hazor and the clan of Heber the Kenite. I 8 Jael came out to meet Sisera, and said to him, "Turn aside, my lord, turn aside to me; have no fear!" So he turned aside to her into the tent, and she covered him with a rug. I9 Then he said to her, "Please give me a little water to drink; for I am thirsty." So she opened a skin of milk and gave him a drink and covered him. $20 \mathrm{He}$ said to her, "Stand at the entrance of the tent, and if anybody comes and asks you, 'Is anyone here?' say, 'No.'” 2 I But Jael, wife of Heber, took a tent peg, and took a hammer in her hand, and went softly to him and drove the peg into his temple, until it went down into the ground - he was lying fast asleep from weariness - and he died. 22 Then, as Barak came in pursuit of Sisera, Jael went out to meet him, and said to him, "Come, and I will show you the man whom you are seeking." So he went into her tent; and there was Sisera lying dead, with the tent peg in his temple.

Conclusion

23 So on that day God subdued King Jabin of Canaan before the Israelites. 24 Then the hand of the Israelites bore harder and harder on King Jabin of Canaan, until they destroyed King Jabin of Canaan.

[The "Song of Deborah" in Judges 5]

5:3 Ib: And thereafter the land had rest for forty years.

\section{DECONSTRUCTING MALE POWER}

The Jael episode is part of a larger compositional effort in Judges to malign the male martial power that both symbolized and undergirded the 
authority of ancient states. Thus, two heroic warriors in the book, Jephthah and Samson, are "brought low" by women (II:35, I 6:I-2I). ${ }^{\mathrm{II}}$ Likewise, when Abimelech besieges the town of Thebez in his quest for monarchic power, a woman drops a millstone from atop the wall on his head. Since weapons of war are reserved for men, she wields an object that symbolizes her domestic place in society. In the same way, when Jael slays Sisera, she brandishes a tent peg, the symbol of her identity as a nomadic Kenite woman who waits in her tent while men fight on the battlefield. ${ }^{\mathrm{I} 2}$

The authors of Judges reshaped the Gideon account so that this mighty warrior becomes an apprehensive and unlikely leader. $\mathrm{He}$ summons the courage to fight only after many divine assurances of success, and his triumph is ascribed to the fact that Yhwh "goes with" him into battle (6:15-16). Similarly, a supplement to our account subordinates the warrior Barak to the authority of Yhwh's prophet Deborah: Barak will not accept this mission unless Deborah "goes with" him $(4: 8,9 b)$.

Barak's demand that Deborah accompany him reflects the anxiety of rulers and their need for oracles assuring them that the deity would be with them in their undertakings. For example, the goddess Ishtar assures the Assyrian ruler Esarhaddon through the mouth of prophet:

Esarhaddon, king of the lands, fear not! What is the wind that has attacked you, whose wings I have not broken? Like ripe apples your enemies will continually roll before your feet. I am the great Lady, I am Ištar of Arbela who throws your enemies before your feet. Have I spoken to you any words that you could not

II The late character of the daughter of Jephthah episode is widely accepted; see the discussion of past research by Thomas Römer, "Why Would the Deuteronomist Tell About the Sacrifice of Jephthah's Daughter?," Journal of the Study of the Old Testament, 77 (1998), 27-38, and David Janzen's response "Why Would the Deuteronomist Tell About the Sacrifice of Jephthah's Daughter?," Journal of the Study of the Old Testament, 29 (2005), 339-357. With respect to the Samson account, many agree that a later author appended chapter I 6 (notice the conclusion in I 5:20); see the discussion in Walter Gross, Richter (Freiburg im Breisgau: Herder, 2009).

${ }^{\text {I2 }}$ In Chapter I3, we explore other ways the account engages in a critique of masculine martial authority. On the subversive quality of Judges, see, most recently, Kelly J. Murphy, Rewriting Masculinity: Gideon, Men, and Might (New York: Oxford University Press, 2019). The depictions of both Deborah and Jael have had a substantial political impact throughout the ages, and that impact is the focus of Joy A. Schroeder's Deborah's Daughters: Gender Politics and Biblical Interpretation (New York: Oxford University Press, 20I4), as well as Colleen M. Conway's Sex and Slaughter in the Tent of Jael: A Cultural History of a Biblical Story (New York: Oxford University Press, 20I7). 
rely upon? I am Ištar of Arbela, I will flay your enemies and deliver them up to you. I am Ištar of Arbela, I go before you and behind you .... ${ }^{\text {I3 }}$

In the biblical corpus, the injunction to "fear not" is also addressed to the king in response to military threats (e.g., Isa. 7:4, 37:6), while other texts portray Israel's monarchs being eager, like Barak, to harness the divine prophetic power for their military campaigns (e.g., I Kings 22; 2 Kings 3). The scribe who added 4:9a allows Deborah to accompany the warrior while using her prophetic power to foretell (and simultaneously interpret) the outcome: "You will receive no glory on the way you are going, for Yhwh will deliver Sisera into the hand of a woman" (cf. Judg. 7:2).

Here and elsewhere, scribes have retouched a tale of triumph, subordinating the role of the male hero to the power of the nation's deity that works through women. As an alternative to the egoism and thirst for glory that motivates male rulers, they imagine the ideal ruler for Israel as a mother (see 5:7). They beckon their (male) readers to embrace her capacity to both protect her people and inspire volunteerism among its members. To be a great leader like Deborah, one must curb the quest for personal honor and social advancement that motivates Barak and many of the other male figures in the book.

The Jael episode dovetails with the gender-bending subversion of macho-monarchic masculinity on display throughout the narrative of the nation's formation. In Part III, we saw how Rahab, as a woman without husband or children, acts maternally by protecting the Israelite spies, hiding them under stalks of flax on her roof and lying at length to the king's men. As one of the next women to appear in the wider narrative, Jael acts in defense of the nation by first seducing its enemy into her tent ("Turn aside to me, my lord, turn aside to me; have no fear!") and then feigning maternal protection - covering him, feeding him milk, and agreeing to stand by the door and lie to those who sought his life. While Rahab lets down the spies from her window, orchestrating their escape as Michal does for David (see I Sam. I9), Sisera's mother is depicted in the following chapter waiting at the

${ }^{\prime} 3$ Translation of SAA 9.I.I, lines I 4'-29', by Martti Nissinen, Prophets and Prophecy in the Ancient Near East (Atlanta: Society of Biblical Literature, 2003), I02-103. For the socalled Mitsein formula, with which the deity promises "I will go with you," see the

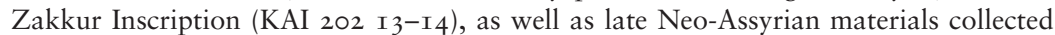
by Manfred Weippert, "Assyrische Prophetien der Zeit Assarhaddons und Assurbanipals" in F. M. Fales (ed.), Assyrian Royal Inscriptions: New Horizons (Roma: Istituto per l'Oriente, I98I), 7 I-II 5 . 
window for her son to return and finds consolation in the thought that he is busy taking maidens captive for his pleasure. ${ }^{\mathrm{I}}$ The reader is invited to compare this Canaanite mother with "a mother in Israel" who mobilizes a nation and leads it to victory (see 5:7). Like Rahab and Deborah, Jael has no children, but whereas Rahab and Deborah also do not have husbands who would stand in their way, Jael is married to a man who sides with the enemy and whom she, in turn, brazenly sidelines in her solidarity with Israel.

\section{MARTIAL VALOR AND MONARCHIC RULE}

To what extent the author of the Jael episode knew of, and consciously played on, similar stories throughout the biblical narrative is difficult to say. What seems more certain is that this author was inspired by the depiction of Deborah's authority in the originally brief account of her commissioning Barak to fight Sisera. That account juxtaposes Deborah and Barak, on one side, with the Canaanite king Jabin and his general Sisera, on the other. Israel's leader is neither a king nor a man, and by issuing instructions to Barak, she thwarts any intention he may have had to leverage his triumph in a bid for monarchic rule (as in the cases of Gideon and Jephthah, or Saul and David, for example).

One of the most striking lines in the account presents Deborah summoning Barak (4:4). Due to Deborah's gender, the line has aroused the consternation of many later male commentators, both Jewish and Christian. But its implications for political theory and political theology are even more radical: Authority here is not predicated on the basis of martial valor, and the role of military leadership is sharply divided from the right to govern. Barak has a purpose to serve, but he, and the male readers of this account, must learn to "stay in their lane." In keeping with the laws of Deuteronomy, in which generals are to be chosen right before battle and a king is nowhere to be found, success on the battlefield does

${ }^{14}$ The motif of the aristocratic woman at the window is a popular one in both ancient texts and images; for example, it's represented in an ivory found at Samaria, as well as on the furniture of the royal couple in the Ashurbanipal relief discussed above. (For a biblical instance of a woman waiting in a window while men go out to battle, see 2 Kings 9:1 4-37, esp. v. 30.) See Claudia Suter, Die Frau am Fenster in der orientalischen Elfenbeinschnitzkunst des frühen I. Jahrtausends $v$. Chr. (Munich: Deutscher Kunstverlag, I992), 7-28. 
not entitle one to wider political prerogatives, let alone offer a legitimate basis for exercising monarchic rule. ${ }^{\mathrm{I}}$

I5 I develop these points in my essays, "Human, All Too Human: Royal Name-Making in Wartime" in Yigal Levin and Amnon Shapira (eds.), War and Peace in the Jewish Tradition: From the Biblical World to the Present (New York: Routledge, 20II), 62-77; "Military Valor and Kingship: A Book-Oriented Approach to the Study of a Major War Theme" in Brad E. Kelle and Frank Ritchel Ames (eds.), Writing and Reading War: Rhetoric, Gender, and Ethics in Biblical and Modern Contexts (Atlanta: Society of Biblical Literature, 2008), 33-56. 